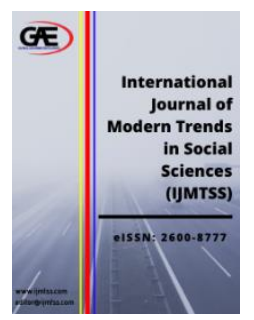

\author{
INTERNATIONAL JOURNAL OF \\ MODERN TRENDS IN \\ SOCIAL SCIENCES \\ (IJMTSS) \\ www.ijmtss.com
}

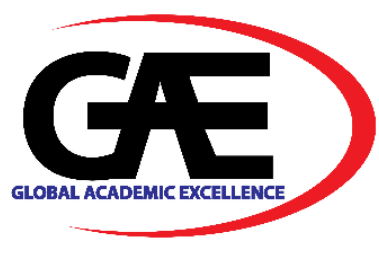

\title{
THE RELATIONSHIP BETWEEN PUBLIC SERVICES MOTIVATION AND ETHICAL LEADERSHIP WITH ORGANIZATION PERFORMANCE AT MILITARY TRAINING ACADEMY, NDUM.
}

\author{
Fauzahani Pairan ${ }^{1 *}$, Jessica Ong Hai Liaw ${ }^{2}$, Mohd Juraimy Kadir ${ }^{3}$, Nora Ibrahim ${ }^{4}$
}

1 Faculty of Defence Studies and Management, National Defense University Malaysia, Malaysia Email: fauza5328@gmail.com

2 Faculty of Defence Studies and Management, National Defense University Malaysia, Malaysia Email: jessica@upnm.edu.my

3 Faculty of Defence Studies and Management, National Defense University Malaysia, Malaysia Email: juraimy@upnm.edu.my

4 Faculty of Defence Studies and Management, National Defense University Malaysia, Malaysia Email: nora_am91@yahoo.com

* Corresponding Author

\section{Article Info:}

\section{Article history:}

Received date: 08.09.2021

Revised date: 30.09 .2021

Accepted date: 10.10.2021

Published date: 01.12.2021

\section{To cite this document:}

Pairan, F., Ong, H. L. J., Kadir, M. J., \& Ibrahim, N. (2021). The Relationship Between Public Services Motivation and Ethical Leadership with Organization Performance at Military Training Academy, NDUM. International Journal of Modern Trends in Social Sciences, 4 (18), 0108 .

DOI: $10.35631 / \mathrm{IJMTSS} .418001$

\begin{abstract}
:
A public organization is an important sector in the administration of the Nation and it needs to remain relevant and accepted by society. The sub-sector such as services and security are the most important organizations that require high performance in society and the country to ensure security is always guaranteed. Military Training Academy, NDUM is an organization involved in various security and humanitarian operations either nationally or internationally. Accordingly, this study was conducted to assess employee motivation in public service activities by using the Public Service Motivation Model (PSM). The elements contained in the model are an attraction to public policymaking, commitment to the public interest, self-sacrifice, compassion, and ethical leadership. This study aims to analyze the relationship between Public Service Motivation (PSM) and organizational performance with ethical leadership among employees in Military Training Academy, NDUM. Quantitative research methods were used and questionnaires have been distributed to staff and instructors in Military Training Academy, NDUM, located in Kuala Lumpur by distributing the questionnaire and analyzed using SPSS 19. The results of this study showed that the attraction towards public policy-making $(\mathrm{t}=1.927, \mathrm{p}>0.01)$, commitment to public interest $(\mathrm{t}=0.289, \mathrm{p}>0.01)$, selfsacrifice $(\mathrm{t}=1.623, \mathrm{p}>0.01)$, compassion $(\mathrm{t}=0.704, \mathrm{p}>0.01)$ and ethical leadership $(\mathrm{t}=7.071, \mathrm{p}<0.01)$. Ethical leadership encourages employees to
\end{abstract}




\section{Introduction}

Public organization is the most important sector in the administration of the Nation and it needs to be relevant and accepted by the society. The security sector is an example of an important organization that requires high performance in the community to ensure safety is always superior. Military Training Academy, NDUM is involved and successfully accomplishes its mission in various operations including public services operation whether national or international by using existing human resources expert and equipment. Military Training Academy, NDUM also helps the State authority to manage and extend humanitarian assistance or deploying state assets when needed by their expert person. However, observation identify there is no research about the preparedness of the Military Training Academy, NDUM staff to involves in the public service activities that giving an impact on the organizational performance. Therefore, the organizational performance needed to measure through identify the level of public service motivation among employees especially in public organization.

\section{Literature Review}

Some research discussions on Public Service Motivation Model (PSM) and ethical leadership in the public sector. In 1990, Perry and Wise were the first scholars to elevate and parse the dimensions of PSM as an important topic in understanding employees and management. PSM is an important aspect in communities and organizations and is seen as a noble value to create quality life in various levels and systems of community life and organizational administration. (Ritz, Brewer, \& Neumann, 2016). Accordingly, organizational commitment in PSM activities is required to improve organizational performance and achieve competitiveness whether for profit or non-profit-based organizations (Clerkin \& Fotheringham, 2017). In addition, PSM positively predicts public employees' job satisfaction, performance, and ethical behavior (Christensen \& Wright, 2018; Chung-An, 2021).

The concept of PSM is used among the businesses organization to motivating employees in managing their jobs well (Perry et al., 2010; Wright, 2007). PSM also focused on the specific motivational properties of public service organizations, including their prevalence, antecedents, and effectiveness (Taehee and Long, 2015). However, the article of Ritz et al. (2016) argue that human resource management practices and PSM are not integrated and ineffective in public organizations, but Perry (1997) and Vandenabeele (2010) state PSM as an effective practice to organizations by introducing several elements to form PSM theory i.e. attraction to public policy making (APM), commitment to the public interest (CPI) (Houstan, 2006).

APM is an important component of PSM as it involves many organizational and individual perceptions of community service activities that can be engaging and dramatic in nature; and it can strengthen one's self-interest image (Perry, 1996). CPI refers to people's motivation to do good in society that exists in various forms of civic behavior outside the workplace, such as formal and informal volunteering (Lee and Jeong, 2015). Volunteering is a key value or event 


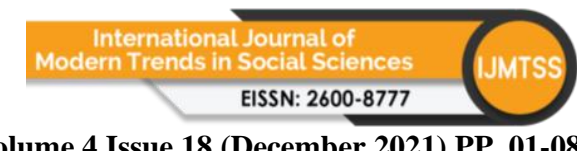

Volume 4 Issue 18 (December 2021) PP. 01-08

DOI 10.35631/IJMTSS.418001

to increase employee interest in participating in public service activities and improve organizational performance (Coursey et. al., 2011; Clerkin and Fotheringham, 2017; Ertas, 2014; Lee and Jeong, 2015; Taylor, 2010). Another element in PSM is self-sacrifice (SS). Choi and Mai-Dalton (1998) define SS as the complete/ partial neglect; and/ or permanent deferral of personal interests, privileges, or well-being in the division of labor, rewards, and training. SS, according to Yorges et al. (1999), defined as giving up or losing something important to an individual. Both of these definitions focus on aspects of SS that involve giving up personal gain. SS contains altruism which is the core of PSM and it describes the extent to which individuals release personal interest in serving others as well as the main core of public service motivation as a whole (Kim \& Vandenabeele, 2010; Chris, 2018)

Last of PSM elements is Compassion (Com), been defined as "an attitude toward others, whether near others or strangers, or the whole of humanity; which contains feelings, cognitions, and behaviors focused on caring, tenderness, and orientation toward supporting, helping, and understand especially to those who suffer or need (Sprecher and Fehr, 2005) or "attitudes toward others who suffer or need" (Radey and Figley, 2007). Development of PSM Philosophy and Framework inspired by Perry \& Wise, 1990 is the motivation for the public service philosophy defined by Rainey (1982) as the individual's tendency to respond to the well-being of society and bring harmony to life and a positive impact to the organization as a public service (Kjeldsen and Hansen, 2018). Civil service states the responsibility of individuals or groups in an organization to society's demands to create a better quality of life (Gawthrop, 1998).

PSM and Organizational Performance are linked in public organizations from employee perspectives such as job satisfaction, individual performance, public sector job choices and work commitment and earnings (Ritz et al., 2016). PSM is also associated with Ethical Leadership (EL) which is critical component that can have a significant impact on individual and organizational attitudes in the workplace. The function of leadership is to create action by using language, symbols, and rituals in developing the way subordinate workers work (Shamir, 1991), which produces positive impact of organizational norms and values (Kuk-Kyoung Changhoon, 2018; Dongkyu \& Christian, 2020). Whereas Ethics is defined as the demonstration of normatively appropriate behavior through personal actions and interpersonal relationships, as well as the promotion of that behavior to followers through two-way communication, reinforcement, and decision-making (Brown et al., 2005). Therefore, the EL is a additional element to measuring the organizational performance especially in the public security organization.

\section{Research Methodology}

This study aims to analyze the relationship between Public Service Motivation (PSM) and organizational performance with ethical leadership among employees in Military Training Academy, NDUM. The study was using quantitative approach to obtained and analysed the data. This study will focus on officers and support workers working in Organization A in Sungai Besi, Kuala Lumpur. The total staff of Military Training Academy, NDUM is 217 people and consists of 49 officers and 168 support levels.

Statistical Package of Social Science (SPSS) version 19.0 was used in this study to analyze the data obtained from the questionnaire. The purpose of the expert survey was to obtain agreement and comment on the proposed model. The panel of experts was selected based on their knowledge and experience related to PSM. Five experts participated in this expert survey. The 
expert panel is selected with at least 3 years experience in PSM or humanitarian assistance. Selection of PSM members based on the focus of a group approach. The number of experts participating in this research is appropriate (Krueger \& Casey, 2000). Table 1 shows the profiles of the expert reviewers in this study.

Therefore, this preliminary investigation shows that the items for public service motivation are acceptable and relevancy to continued this study at Military Training Academy, NDUM. As a result of detailed interviews, questionnaires was developed to obtain information and data. A pilot study was conducted before the actual study was conducted. This was done to confirm that the questionnaire items were constructed according to the terms and language appropriate for the study. A pilot study and questionnaire was conducted on administrators of Military Training Academy to 40 subordinates using GoogleForm on February 9, 2021 and various information obtained from discussions with respondents related to the importance and relevance of questions to the study, correct language use, and the level of understanding of each item to the respondents. The interview with 5 expert in humanitarian and disaster operation have been conducted in February, 2021 and suggests the questionaire is adequated to measure PSM and EL and impact on the Organization Performance at Military Training Academy, NDUM. The results of the suggestions and respondents information was used to adapt and refine each pilot study item to the actual research item. The results of a pilot test that identified Cronbach Alpha for each variable score more than 0.8 and are good for actual studies.

Table 1: $\quad$ Expert Reviewer Profile

\begin{tabular}{|l|l|l|l|l|}
\hline \multicolumn{1}{|c|}{ Detail } & \multicolumn{1}{|c|}{ Appointment } & \multicolumn{1}{c|}{$\begin{array}{c}\text { Length of } \\
\text { Service }\end{array}$} & $\begin{array}{c}\text { Type of } \\
\text { Department }\end{array}$ & \multicolumn{1}{c|}{$\begin{array}{c}\text { Education } \\
\text { Level }\end{array}$} \\
\hline Expert 1 & $\begin{array}{l}\text { Chief of } \\
\text { Operation }\end{array}$ & 28 years & Administration & Master Degree \\
\hline Expert 2 & $\begin{array}{l}\text { Chief of } \\
\text { Department }\end{array}$ & 27 years & Administration & Master Degree \\
\hline Expert 3 & Account Officer & 23 years & Administration & Degree \\
\hline Expert 4 & Chief Clerk & 24 years & Administration & SPM \\
\hline Expert 5 & Clerk & 14 years & Administration & SPM \\
\hline
\end{tabular}

Furthermore, the actual study was conducted with an online approach and collected 138 sets of questionnaires from officers and support staff of Military Training Academy, NDUM in Sg Besi, Kuala Lumpur. The feedback was used to analyze the level of the PSM and EL on Organizational Performance and used a sampling base on Krejcie and Morgan (1970). Analysis was conducted to covers demographic characteristics, overall factors of PSM Model, EL and Organizational Performance, demographic characteristics, demographic characteristics and their relationship with PSM Model and relationship contributing factors to Organizational Performance among employees in Military Training Academy, NDUM.

\section{Findings}

\section{Respondents Demographic}

Demography respondents was conduct to analyze the relationship between Organization A instructors and staff PSM and EL towards Organization Performance as a whole according to 


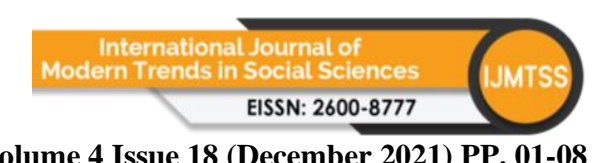

Volume 4 Issue 18 (December 2021) PP. 01-08 DOI 10.35631/IJMTSS.418001

demographic characteristics i.e. gender, age, marital status, duration of service and salary + allowance. Observations from the demographic data identify the majority of respondents is Male with $126(91.3 \%)$ respondents and $12(8.7 \%)$ is Female. Age data shows $85(61.6 \%)$ respondents is age between 31-40 years; follow by 21 (29\%) respondents age between 21-30 years; $22(15.9 \%)$ respondents age between $41-50$ years; and $2(1.4 \%)$ respondents age 51 years and above. The marital status data shows $108(78.3 \%)$ respondents is married and $27(19.6 \%)$ is single. Duration of service result shows majority respondents was serving in organization A. for more than 16 years with $74(53.6 \%)$ respondents. The majority $90(65.2 \%)$ respondents is SPM qualification; and follow by Diploma and above with 31 (22.5\%) respondents. Majority respondents have family commitment between 3-5 family members with 67 (48.6\%) respondents. According to salary + allowance, majority respondents have received RM2,501.00 - RM4,500 with 63 (45.7\%) respondent's; and follows by below RM2,500.00 income per month with 44 (31.9\%) respondents. Therefore, the demography result shows the maturity of respondents is high with majority are more than 31 years old and married. The majorities respondents have been serves for more than 16 years in MTA and get income more than RM2501.00 per month.

\section{Descriptive Analysis}

This section defines respondents descriptions of the PSM Model and EL as independent variables and relationships with dependent variables (Organizational Performance) among officers and supporting staff. Responses was assessed on a five -point Likert scale where $1=$ strongly disagree, $2=$ disagree, $3=$ disagree, $4=$ agree and $5=$ strongly agree. The result shows most of the data have high score with mean value more than 3.50 (high score). The most high mean score is "I would agree to a good plan to make a better life for the poor, even if it cost me money" $=4.19$. The most of SD value is close to mean score which meaning the curve of the data slim to mean.

\section{Factor Analysis}

In this study, the Kaiser-Meyer-Olkin (KMO) measures how suited is the data collected for Factor Analysis. KMO value would range from 0 to 1.

\section{Total Variance Explained}

Which labeled the Initial Eigenvalues, Extracted Components and Rotated Components. This result demonstrated that 67 components cumulatively explained $100.00 \%$, and consequently, it could be stated that $100 \%$ of items which assessed intention was included in the model. Having said that, Factor 1 explained $55.305 \%$, Factor 2 explained $7.250 \%$ and Factor 3 explained $3.505 \%$ and decreased until Factor 67 with explained $0.014 \%$ which total Initial Eigenvalues Cumulative Percentage is $100 \%$. The Age data shows almost $r$ value close to 0 and only Commitment to Public Interest $(r=0.750)$ value close to 1 , but weak correlation (Ramlan \& Adnan, 2016). According to Duration of Service, two items shows the negative $r$ value which is Commitment to Public Interest ( $\mathrm{r}=-0.037)$ and Compassion ( $\mathrm{r}=-0.016)$. The strongest correlation $r$ value is Attraction to Public Policy Making ( $r=0$. 135); follows by Organization Performance ( $r=0.046)$; and Self Sacrifice $(r=0.045)$. The Age and Duration of Length shows there were no relationship between Age and Duration of Service with PSM and Organization Performance.

\section{Regression Analysis}

Regression analysis was conduct to acknowledge the relationship between the contributing factors as a whole among the employee instructors and staff. The result shows the Significant 
F Change value of 0.000 (Less than 0.05 ) implies that the model for intention is significant at the $84.3 \%$ percept significant level. The value $\mathrm{R}=0.843$, indicated that the level of prediction to assess Organization Performance was high. Adjusted $\mathrm{R}^{2}$ value, (coefficient of the determination) 0.699 indicated that $69.9 \%$ of Organization Performance could be explained by the 5 independent variables.

The standardized coefficients $(\beta)$ estimated how strongly the explanatory variables influenced the dependent variable (Ramlan \& Adnan, 2016). Where Constant $=0.404$, shows that if PSM are all rated as zero, Organization Performance would be $0.404 . \beta 1=0.195$, shows that one unit change in Attraction to Public Policy Making results in 0.195 units increase in Organization Performance; $\beta 2=0.030$, shows that one unit change in Commitment to Public Interest, results in 0.030 units increase in Organization Performance; $\beta 3=0.159$, shows that one unit change in Self Sacrifice, results in 0.159 units increase in Organization Performance; $\beta 4=0.074$, shows that one unit change in Compassion, results in 0.074 units increase in Organization Performance; $\beta 5=0.444$, shows that one unit change in Ethical Leadership, results in 0.444 units increase in Organization Performance. The magnitude of the coefficients of the independent variables also denoted the strength of the influence that they have on the dependent variable.

The results indicate Organization Performance is strongly influenced by Ethical Leadership (coefficient $\beta 4=0.444$ ), Attraction to Public Policy Making (coefficient $\beta 4=0.195$ ), SelfSacrifice (coefficient $\beta 14=0.159$ ), Compassion (coefficient $\beta 4=0.074$ ) and Commitment to Public Interest (coefficient $\beta 4=0.030$ ). All independent variables show the positive regression coefficient indicates a direct proportionality in increase to Organization Performance and the higher significant is EL (coefficient $\beta 4=0.444$ ). As result, the relationship between the contributing factors among MTA employee's is moderate. According to the multivarian relation findings the relation between PSM toward organization performance. The result show attraction towards public policy making $(\mathrm{t}=1.927, \mathrm{p}>0.01)$, commitment to public interest $(\mathrm{t}=0.289, \mathrm{p}>0.01)$, self-sacrifice $(\mathrm{t}=1.623, \mathrm{p}>0.01)$, compassion $(\mathrm{t}=0.704, \mathrm{p}>0.01)$ and ethical leadership $((\mathrm{t}=7.071, \mathrm{p}<0.01)$. Ethical leadership encourages employees to participate in community service programs and improve organizational performance.

\section{Conclusion}

For the conclusion, this concept focuses on employee behavior, attitudes and culture in producing young officers with education and becoming better employees and front lines with good life values. This study provides information on PSM and EL among instructors and general duty officers on Organizational Performance. The EL have a significant impact on the Organization Performance in Military Training Academy, NDUM. Therefore, this study allows human resources to plan to develop appropriate methods to improve organizational performance by focusing on EL factor in Military Training Academy, NDUM. As a security organization, the ethical leadership among their Officer's is a most important to motivated the subordinates to involved any public service especially during peacetime.

\section{References}

Bromberg D. E. \& Charbonneau E. (2019). Public Service Motivation, Personality, and The Hiring Decisions of Public Managers: An Experimental Study.

Brown, M. E., Trevino, L. K., \& Harrison, D. A. (2005). Ethical Leadership: A Social Learning Perspective for Construct Development and Testing. Organizational Behavior \& Human Decision Processes, 97, 117-134. 
Chua, Y. P. (2006). Kaedah Penyelidikan. Kuala Lumpur: McGraw Hill

Chung-An, Chih-W.H, \& Don Y. C. (2021). Can Training Enhance Public Employees' Public Service Motivation? A Pretest-Posttest Design, Review of Public Personnel Administration 2021, Vol. 41(1) 194-215

Choi \& Mai-Dalton. (1998). On the Leadership Function of Self-Sacrifice", Leadership Quarterly, 9(4) 475-502

Chris O'Leary. (2018). Public Service Motivation: A Rationalist Critique, Public Personnel Management 2019, Vol. 48(1) 82-96

Clerkin, R., \& Fotheringham, E. (2017). Exploring the Relationship Between Public Service Motivation and Formal and Informal Volunteering. Journal of Public and Nonprofit Affairs, 3(1), 23-39.

Dongkyu \& Christian, (2020). Ethical Leadership and Team Ethical Voice and Citizenship Behavior in the Military: The Roles of Team Moral Efficacy and Ethical Climate, Group \& Organization Management, Vol. 45(4) 514-555

Ertas, N. (2014). Public Service Motivation Theory and Voluntary Organizations: Do Government Employees Volunteer More?" Nonprofit and Voluntary Sector Quarterly 43(2):254-71.doi:10.1177/0899764012459254.

Grawthrop .(1998). Public Service and Democrary: Ethical Imperatives for the 21 st century, Public Administration and Public Policy, NY (Book)

Hassan, S., Mahsud, R., Yukl, G., \& Prussia, G. E. (2013). Ethical and Empowering Leadership and Leader Effectiveness. Journal of Managerial Psychology, 28, 133-146.

Houston, D. (2006). Walking the Walk of Public Service Motivation: Public Employees and Charitable Gifts of Time, Blood, and Money."Journal of Public Administration Research and Theory 16(1), 67-86. doi:10.1093/jopart/mui028.

Kjeldsen A. M. \& Hansen, J. R. (2018). Sector Differences in the Public Service Motivation Job Satisfaction Relationship: Exploring The Role of Organizational Characteristics 2 (6)

Krejcie, R. V., \& Morgan, D. W. (1970). Determining Sample Size for Research Activities. Educational and Psychological Measurement. 30. pp. 607-610

Kuk-Kyoung Moon \& Changhoon Jung. (2018). Management Representativeness, Ethical Leadership, and Employee Job Satisfaction in the U.S. Federal Government, Public Personnel Management 2018, Vol. 47(3) 265-286

Lee, Y. J. \& J. W. Jeong. (2015). The Link between Public Service Motivation and Volunteering: The Case of South Korean Civil Servants." International Journal of Public Administration 38(5), 355-63. doi:10.1080/01900692.2014.938819

Perry, J. L., Hondeghem, A., \& Wise, L. R. (2010). Revisiting the Motivational Bases of Public Service: Twenty Years of Research and An Agenda for the Future. Public Administration Review, 70, 681-690.

Perry, J. L. (1996). Measuring Public Service Motivation: An Assessment of Construct Reliability and Validity. Journal of Public Administration Research and Theory, 6, 522.

Perry, J. L. (1997). Antecedents of Public Service Motivation. Journal of Public Administration Research and Theory, 7, 181-197

Perry, J. L., \& Wise, L. R. (1990). The Motivational Bases of Public Service. Public Administration Review, 50, 367-373.

Ritz, A., G. Brewer, \& O. Neumann. (2016). Public Service Motivation: A Systematic Literature Review and Outlook." Public Administration Review 76 (3), 414-26. doi:10.1111/puar.12505. 
Radey \& Figley. (2007). The Social Psychology of Compassion. Clinical Social Work Journal $35,207-214$.

Ramlan, H., \& Adnan, M. S. (2016). The Profitability of Islamic and Conventional Bank: Case Study in Malaysia. Procedia Economics and Finance, 359-367. doi:10.1016/S22125671(16)00044-7

Rainey, H. G. (1982). Reward Preferences Among Public and Private Managers: In Search of the Service Ethic. American Review of Public Administration, 16, 288-302.

Sabine, L. \& Brian, S. E. 2004, A Handbook of Statistical Analyses using SPSS, Chapman \& Hall/CRC Press LLC, New York Washington, D.C

Shamir, B. (1991). Meaning, Self and Motivation In Organizations. Organization Studies, 12, 405-424

Sprecher, S., \& Fehr, B. (2005). Compassionate Love for Close Others and Humanity. Journal of Social and Personality Relationships, 22, 629-651 DOI:10.1177/0265407505056439

Taehee K., Alexander C. H., \& Tae H. E. (2015). At The Front Line: Examining The Effects of Perceived Job Significance, Employee Commitment, and Job Involvement on Public Service Motivation, International Review of Administrative Sciences, 81(4),713-733, Doi: $10.1177 / 0020852314558028$

Taylor, J. (2010). Public Service Motivation, Civic Attitudes and Actions of Public, Nonprofit and Private Sector Employees." Public Administration 88(4), 1083-98. doi:10.1111/j.1467-9299. 2010.01870.x.

Trevino, L. K., Hartman, L. P., \& Brown, M. (2000). Moral Person And Moral Manager: How Executives Develop a Reputation for Ethical Leadership. California Management Review, 42, 128-142.

Vandenabeele \& Kim. (2010). A Strategy for Building Public Service Motivation Research Internationally, Public Administration Review 70(5):701-709 DOI:10.1111/j.15406210.2010.02198.x

Wright, P. M., \& Kehoe, R. R. (2007). Human resource practices and organizational commitment: A deeper examination. Asia Pacific Journal of Human Resources, 46(1), 6.

Yorges, S.L., Weiss, H.M. \& Strickland, O.J. (1999).The Effect of Leader Outcomes on Influence, Attributions and Perceptions of Charisma, Journal of Applied Psychology, $84,428-36$

Zikmund, W. (2000). Business Research Methods (6 ${ }^{\text {th }}$ ed.) Fort Worth: The Dryden Press 